\title{
Foreword. Museology in tribal contexts
}

Bruno Brulon Soares

\section{OpenEdition}

\section{Journals}

Electronic version

URL: https://journals.openedition.org/iss/2979

DOI: 10.4000/iss.2979

ISSN: 2306-4161

\section{Publisher}

ICOM - International Council of Museums

\section{Printed version}

Date of publication: 18 December 2021

Number of pages: 9-10

ISBN: 978-92-9012-446-7

ISSN: 2309-1290

\section{Electronic reference}

Bruno Brulon Soares, "Foreword. Museology in tribal contexts", ICOFOM Study Series [Online], 49-1 I 2021, Online since 18 December 2021, connection on 08 January 2022. URL: http://

journals.openedition.org/iss/2979; DOl: https://doi.org/10.4000/iss.2979 


\section{Foreword}

\section{Museology in tribal contexts}

This new issue of the ICOFOM Study Series brings together the full articles presented at the ICOFOM Annual Symposium of 2020 under the theme "Museology in Tribal Contexts", organised in virtual format by Southern New Hampshire University in the United States. This symposium was conceived by ICOFOM with the support of the International Council of Museums-US, the Association of African American Museums, and Southern New Hampshire University. It aimed to invite speakers engaged in Indigenous practices in order to inspire the critical conception of museological theory from their own tribal perspectives and indigenous understandings of cultural heritage and museums.

Though based in the United States, this online symposium made it possible to gather ICOFOM members from different contexts around the globe, registering participants from 48 different countries, and to engage museum professionals in a decolonial approach to museum theory. The assumption that Indigenous perspectives on the museum can help to open museology to other epistemologies and situated interpretations of cultural heritage was at the centre of the debates fostered by this fruitful event. The decolonisation of museology is an active and continuous exercise that ICOFOM has been addressing with the research project "Museums, Community Action and Decolonisation", whose results have inspired a series of webinars and, certainly, the conception of this annual symposium organised during the pandemic of COVID-19. This critical moment for our societies and for museums globally has made explicit some of the structural problems of our current era and raised some fundamental questions about the participation of different groups, including minorities, in the cultural sector.

We hope that the articles selected for this issue can help shed a light on museology's present-day challenges as it addresses some of the key problems that the theory as we know it was not able to address in the past. Thus, the articles deal with various topics, from repatriation to the relations of museums with the art market and the right of Indigenous people make themselves authors of their own representation in museums. In this sense, this issue is the first part of a debate on "decolonising museology" that was taken on as a core theme of this journal for 2021, and that will be further explored in our upcoming volume later this year.

I'm grateful to all the members of our Editorial Board and the peer reviewers who have been working hard in the past months so that the ICOFOM Study Series 
could continue as an active publication, even in challenging times. This issue was the result of the direct editorial work of several professionals, among them the guest editors Yun Shun Susie Chung and Robert Denning from Southern New Hampshire University, our partners throughout this journey; the editorial secretaries Anna Leshchenko, Marion Bertin, Lynn Maranda, Elizabeth Weiser and Scarlet Galindo Monteagudo; and the proof-readers Katherine Sleight, Marie-Alix Molinié-Andlauer, and Sophia Tidwell, all of whom have done an outstanding job. Finally, to all the authors of the articles here presented, thank you for sharing your enriching experiences and for paving the way for new perspectives on tribal and localised museologies.

Bruno Brulon Soares

Rio de Janeiro, Brazil 